\title{
Intermittent exotropia: comparative surgical results of lateral recti-recession and monocular recess-resect
}

\author{
Exotropia intermitente:comparaçãodos resultados cirúrgicos entre \\ retrocesso dos retos lateraise retrocesso-ressecção monocular
}

\author{
Vanessa Macedo Batista Fiorelli ${ }^{1}$ \\ Mauro Goldchmit ${ }^{2}$ \\ Carlos Fumiaki Uesugui ${ }^{3}$ \\ Carlos Souza-Dias ${ }^{4}$
}

\footnotetext{
Trabalho realizado no Departamento de Oftalmologia da Faculdade de Ciências Médicas da Santa Casa de São Paulo - São Paulo (SP) - Brasil.

${ }^{1}$ Third year fellow of the Cornea and External Disease Sector of the Ophthalmology Department of the "Santa Casa de Misericórdia de São Paulo" - São Paulo (SP) Brazil.

${ }^{2}$ Doctor Professor and Chief of the Strabismus Section of the Ophthalmology Department of the "Santa Casa de Misericórdia de São Paulo" - São Paulo (SP) - Brazil. ${ }^{3}$ Professor of the Strabismus Section of the Ophthalmology Department of the "Santa Casa de Misericórdia de São Paulo" - São Paulo (SP) - Brazil.

${ }^{4}$ Head Professor of the Strabismus Section of the Ophthalmology Department of the "Santa Casa de Misericórdia de São Paulo" - São Paulo (SP) - Brazil.

Address for correspondence: Vanessa Macedo Batista Fiorelli. Alameda Alemanha, 106 - Bragança Paulista (SP) CEP 12910-035

E-mail: fiorelliliv@uol.com.br

Recebido para publicação em 29.03.2006

Última versão recebida em 20.08.2006 Aprovação em 22.08.2006

Nota Editorial: Depois de concluída a análise do artigo sob sigilo editorial e com a anuência do Dr. Eric Pinheiro de Andrade sobre a divulgação de seu nome como revisor, agradecemos sua participação neste processo.
}

\begin{tabular}{l} 
ABSTRACT \\
\hline Purpose: To compare the results between recession of the lateral recti and \\
monocular recess-resect procedure for the correction of the basic type of \\
intermittent exotropia. Methods: 115 patients with intermittent exotropia \\
were submitted to surgery. The patients were divided into 4 groups, \\
according to the magnitude of preoperative deviation and the surgical \\
procedure was subsequently performed. Well compensated orthophoria \\
or exo-or esophoria were considered surgical success, with minimum of 1 \\
year follow-up after the operation. Results: Success was obtained in $69 \%$ \\
of the patients submitted to recession of the lateral recti, and in $77 \%$ \\
submitted to monocular recess-resect. In the groups with deviations \\
between 12 PD and 25 PD, surgical success was observed in $74 \%$ of the \\
patients submitted to recession of the lateral recti and in $78 \%$ of the patients \\
submitted to monocular recess-resect. (p=0.564). In the group with devia- \\
tions between 26 PD and 35 PD, surgical success was observed in $65 \%$ out \\
of the patients submitted to recession of the lateral recti and in $75 \%$ of the \\
patients submitted to monocular recess-resect. (p=0.266). Conclusion: \\
recession of lateral recti and monocular recess-resect were equally effective \\
in correcting basic type intermittent exotropia according to its preoperative \\
deviation in primary position.
\end{tabular}

Keywords: Exotropia/surgery; Oculomotor muscles; Ophthalmologic surgical procedures; Visual acuity; Comparative study

\section{INTRODUCTION}

Intermittent exotropia $[\mathrm{X}(\mathrm{T})]$ is a disorder of the oculomotor system, characterized by intermittent divergence deviation of the visual axes, with normal retinal correspondence and good surgical prognosis ${ }^{(1)}$.

Surgery gives satisfactory results, but quite frequently, more than one operation is needed to obtain stable orthophoria ${ }^{(1-4)}$. In spite of the disagreement regarding the best surgical approach, the two basic types are: recession of both lateral recti muscles and the monocular recess-resect procedure ${ }^{(1)}$.

The advantages of monocular surgery include low incidence of overcorrections and less risk of complications ${ }^{(5-6)}$, however, it may cause a larger number of undercorrections ${ }^{(7)}$. Some authors state that isolated recession of the lateral recti provides more stable surgical results ${ }^{(2,8)}$.

In different studies, the success rate using the monocular recess-resect procedure varies from $55 \%-82 \%(7,9-10)$ and with recession of lateral recti it varies from $52 \%-69 \%{ }^{(4,7,11-14)}$.

In the literature, there are few comparative studies between the two 
procedures. Valenzuela performed the monocular recessresect procedure in 47 patients obtaining a 55\% success rate and recession of the lateral recti in 78 patients, obtaining $54 \%$ success rate, after a 2 year follow up ${ }^{(8)}$. Orthotropia, exophoria \pm 10 DP or esophoria \pm 5 DP was considered to be a satisfactory result and significant differences were not observed between the two procedures.

One author obtained success in $10(52 \%)$ out of the 19 patients who had recession of the lateral recti, and success in $14(82 \%)$ out of the 17 patients submitted to the monocular recess-resect procedure ${ }^{(10)}$. Orthophoria $\pm 10 \mathrm{DP}$, basic deviations with 1 year post operative follow up was considered to be a satisfactory result. He concluded that monocular surgery gave better results in the basic type of $\mathrm{X}(\mathrm{T})$ in comparison with bilateral surgery, in spite of having obtained a nonsignificant difference between the results of the surgical procedures performed.

Other authors $^{(10)}$, in 2001, compared 103 cases of $\mathrm{X}(\mathrm{T})$ of the basic type and pseudo-divergence excess, considering orthotropia $\pm 10 \mathrm{DP}$ as surgical success, after a 1 year followup period ${ }^{(11)}$. They obtained success in $26(56 \%)$ out of the 46 patients submitted to recession of the lateral recti, and in 34 (60\%) out of the 57 patients submitted to monocular recessresect procedure. There was no statistically significant difference between the surgical results in either of the procedures.

Recent systematic review lead to the conclusion that recession of the lateral recti produces better results for the correction of the divergence excess type of $\mathrm{X}(\mathrm{T})$, and there was no conclusion regarding which procedure was best for correction $\mathrm{X}(\mathrm{T})$ of the basic type $\mathrm{e}^{(12)}$.

Due to the large variability of the results achieved with identical surgical procedures in patients with $\mathrm{X}(\mathrm{T})$, with the same angle of deviation, the aim of this study was to compare the surgical results between recession of the lateral recti (LR recession) and the monocular recess-resect procedure, for the correction of $\mathrm{X}(\mathrm{T})$ of the basic type.

\section{METHODS}

Charts of 115 patients with $\mathrm{X}(\mathrm{T})$ operated on between 1991 and 2001 were retrospectively reviewed. Data of age, sex, refraction, duration and preoperative deviation and follow-up are presented in chart 1 . The inclusion criteria were: basic type $\mathrm{X}(\mathrm{T})$ up to 35PD with normal stereopsis (Titmus or Lang test), follow up $\geq 1$ year, minimum age at surgery of 5 years, visual acuity $\geq 20 / 25$, no previous surgery, absence of vertical incomitance and no previous history of surgery and/or associated eye diseases. This study was approved by the Medical Ethics Committee of "Santa Casa of São Paulo" (number: 018/03).

Deviations were measured, for distance and nearness, with the alternate prism and cover test.

Surgical planning, according to the preoperative angle in primary position, for $L R$ recession, ranged from 5 to $8 \mathrm{~mm}(6.2 \pm$ $0.9)$ and for monocular operation, lateral rectus recession ranged from 4 to $8 \mathrm{~mm}(5.9 \pm 1.0)$ and medial rectus resection from 4 to $6 \mathrm{~mm}(4.7 \pm 0.6)$. Monocular recess-resect was performed in 66 $(57.4 \%)$ patients and recession of lateral recti in $49(42.6 \%)$

The patients were divided into 4 groups:

- Group 1A ( $\mathrm{n}=23)$ : X(T) 12 PD - 25 PD, submitted to LR recession.

- Group 1B (n=46): X(T) 12 PD - 25 PD, submitted to monocular recess-resect.

- Group 2A (n=26): X(T) 26 PD - 35 PD, submitted to LR recession.

- Group 2B ( $\mathrm{n}=20$ ): $\mathrm{X}(\mathrm{T}) 26 \mathrm{PD}$ and $35 \mathrm{PD}$, submitted to monocular recess-resect.

Orthophoria or well compensated exo- or esophoria were considered surgical success.

The Mann-Whitney test was applied to compare the corrections obtained between the groups $1 \mathrm{~A}$ and $1 \mathrm{~B}$, and between the groups $2 \mathrm{~A}$ and $2 \mathrm{~B}$, and with the purpose of studying the association between surgical success, post-operative under-correction and overcorrection. The level of rejection of the null hypothesis was set at 0.05 or $5 \%(\alpha \leq 0.05)$.

\section{RESULTS}

Among the total patients included in this study, thirty four (69\%) of the 49 patients submitted to LR recession, and 51 (77\%) of the 66 patients submitted to monocular recess-resect obtained results considered to be success.

The results are shown in tables I, II and III.

\section{DISCUSSION}

The surgical success obtained in this study in patients with $\mathrm{X}(\mathrm{T})$ submitted to $\mathrm{LR}$ recession was $69 \%$, similar to other

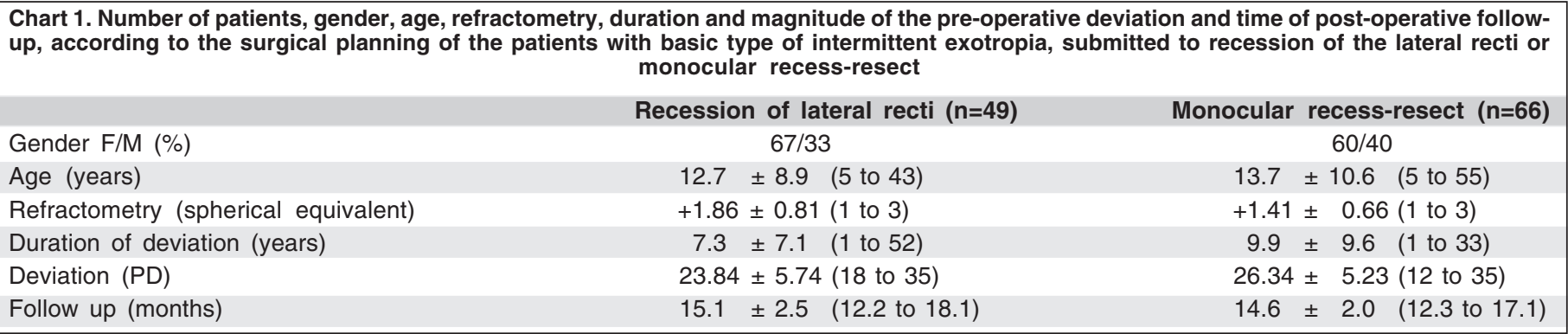


studies $^{(4,7-8,10,12-14)}$. Due to the tendency in $\mathrm{X}(\mathrm{T})$ for the eyes to progress towards divergence reoperations are not indicated within the first year ${ }^{(1,15)}$. In our study reoperation was indicated in $15(31 \%)$ patients.

In the monocular recess-resect group, success was observed in $51(77 \%)$ patients, similar to Kushner's series ${ }^{(9)}(82 \%)$ but higher than Valenzuela's ${ }^{(7)}(55 \%)$ and Lee, Lee's ${ }^{(10)}(60 \%)$ series. In this group, 15 (23\%) cases had indication for reoperation.

In agreement with another study ${ }^{(10)}$, our statistical analysis demonstrated that the differences were not significant between the two procedures, althought other publications considered recess-resect a better procedure for basic $\mathrm{X}(\mathrm{T})^{(4,8,12,15-16)}$.

Some authors ${ }^{(7)}$, considering both monocular and bilateral surgery together, observed $42(32 \%)$ undercorrections and 15 (11\%) overcorrections in the 131 patients operated on, after 2 years of follow-up. Other authors ${ }^{(10)}$, however, after 1 year of follow-up, observed that of the 46 patients submitted to LR recession, $17(37 \%)$ presented with undercorrection and 3 (6\%) presented overcorrection, while of the 57 patients submitted to monocular recess-resect, 17 (30\%) presented with undercorrection and $6(10 \%)$ with overcorrection, with no statistically significant difference between these results.

In the present study, in the group of patients with deviations between $12 \mathrm{PD}$ and $25 \mathrm{PD}$, submitted to LR recession, 5 (22\%) undercorrections and $1(4 \%)$ overcorrection were ob-

\begin{tabular}{|c|c|c|c|}
\hline & Group $1 \mathrm{~A}$ & Group 1B & Total \\
\hline Success & 17 (74\%) & $36(78 \%)$ & 53 \\
\hline Undercorrection & $5(22 \%)$ & $9(20 \%)$ & 14 \\
\hline Overcorrection & $1(4 \%)$ & $1(2 \%)$ & 2 \\
\hline Total & 23 & 46 & 69 \\
\hline
\end{tabular}

Table 2. Patients with basic type of intermittent exotropia, with deviations between $26 \mathrm{PD}$ and $35 \mathrm{PD}$, submitted to LR recession (Group 2A) and monocular recess-resect (Group 2B)

\begin{tabular}{lccr} 
& Group 2A & Group 2B & Total \\
Success & $17(65 \%)$ & $15(75 \%)$ & 32 \\
Undercorrection & $9(35 \%)$ & $5(25 \%)$ & 14 \\
Overcorrection & 0 & 0 & 0 \\
Total & 26 & 20 & 46 \\
Mann-Whitney test (success: group 2A x group 2B p=0.266) & \\
\hline
\end{tabular}

served, and in the group submitted to monocular recessresect, there were $9(20 \%)$ undercorrections and 1 (2\%) overcorrection (Table I). For the deviations between 26 PD e 35 PD, no overcorrections were observed, but 9 (35\%) undercorrections were observed in the group submitted to LR recession and $5(25 \%)$ in the monocular recess-resect goup (Table II). Fewer overcorrections than in the literature were found ${ }^{(7-8,14,16-17)}$. The occurrence of undercorrections, when groups $1 \mathrm{~A}$ and $1 \mathrm{~B}$ are compared (deviations between $12 \mathrm{PD}$ and $25 \mathrm{PD}$ ) with $2 \mathrm{~A}$ and 2B (deviations between $26 \mathrm{PD}$ and $35 \mathrm{PD}$ ), was shown to be higher in this group, however, there are no comparative studies in the literature, relative to surgical success for different magnitudes of deviation.

Some authors ${ }^{(4,8,10-11,13-14)}$ considered orthotropia $\pm 10 \mathrm{PD}$, as the criterion for assessing surgical success. However, this criterion may be considered valid only for surgeries with cosmetic purposes. The main purpose of surgery for the correction of $\mathrm{X}(\mathrm{T})$ is to obtain stable binocular vision. Taking this into consideration, well compensated orthophoria or exo-or esophoria were considered to be surgical success in this study, after minimum follow-up of 1 post-operative year.

Lateral incomitance was considered to be an important factor of persistent overcorrection ${ }^{(18)}$. Some authors disagree and believe that, although a certain esotropia to lateroversion may remain after surgery, it generally tends to reduce over the course of time. For this reason, the authors planned these surgeries, based on the magnitude of the deviation for distant fixation in primary position ${ }^{(3,16)}$.

\section{CONCLUSION}

It was concluded that in patients with the basic type of $\mathrm{X}(\mathrm{T})$, for both preoperative deviations between $12 \mathrm{PD}$ and $25 \mathrm{PD}$ and between $26 \mathrm{PD}$ and $35 \mathrm{PD}$, submitted to LR recession or monocular recess-resect, the two procedures can be considered to be equally effective, there being no difference between the magnitude of the pre-operative exotropia and the correction obtained.

\section{ACKNOWLEDGMENT}

We would like to acknowledge the educational support from NAP ("Núcleo de Apoio a Publicações") of "Santa Casa de São Paulo" - Faculty of Medical Sciences for the editorial assistance.

\begin{tabular}{|c|c|c|c|c|c|c|}
\hline \multirow[t]{2}{*}{ Deviation } & \multicolumn{3}{|c|}{ LR recession } & \multicolumn{3}{|c|}{ Monocular recess-resect } \\
\hline & Pré- & Pós- & Correction & Pre- & Post- & Correction \\
\hline $12-25$ PD & $M=21.56 \pm 2.64$ & $M=8.20 \pm 6.63$ & $M=14.86 \pm 8.72$ & $M=20.93 \pm 3.86$ & $M=6.13 \pm 6.2$ & $M=16.45 \pm 7.09$ \\
\hline $26-35$ PD & $M=30.57 \pm 2.61$ & $M=10.70 \pm 7.70$ & $M=21.11 \pm 9.00$ & $M=30.55 \pm 3.03$ & $M=9.00 \pm 6.5$ & $M=21.70 \pm 9.23$ \\
\hline
\end{tabular}




\section{RESUMO}

Objetivo: Comparar os resultados entre o retrocesso dos retos laterais e retrocesso-ressecção monocular, para correção de exotropia intermitente do tipo básico. Métodos: Foram selecionados 115 prontuários de pacientes portadores de exotropia intermitente do tipo básico submetidos a cirurgia no período entre janeiro de 1991 e dezembro de 2001. Os planejamentos cirúrgicos seguiram orientação do setor de Motilidade Extrínseca Ocular da Clínica Oftalmológica da Santa Casa de São Paulo e basearam-se na magnitude do desvio na posição primária do olhar. Os pacientes foram divididos em 4 grupos, de acordo com a magnitude de desvio pré-operatório (desvios entre $12^{\Delta}$ e $25^{\Delta}$ ou entre $26^{\Delta}$ e $35^{\Delta}$ ) e o procedimento cirúrgico realizado. Considerou-se como sucesso cirúrgico a ortoforia ou exo ou esoforia bem compensada, no mínimo 1 ano após a operação. Resultados: Dos 115 pacientes estudados, 34 (69\%) dos 49 pacientes submetidos ao retrocesso dos retos laterais e $51(77 \%)$, dos 66 pacientes submetidos ao retrocessoressecção monocular, obtiveram sucesso cirúrgico. Em relação aos grupos com desvios entre $12^{\Delta}$ e $25^{\Delta}$, observou-se sucesso em 17 (74\%) dos 23 pacientes submetidos ao retrocesso dos retos laterais (1A) e em 36 (78\%) dos 46 submetidos ao retrocesso-ressecção monocular (1B) $(\mathrm{p}=0,564)$. No segundo grupo (desvios entre $26^{\Delta}$ e $35^{\Delta}$ ), observou-se sucesso de 17 (65\%) dos 26 pacientes submetidos ao retrocesso dos retos laterais (2A) e em 15 (75\%) dos 20 submetidos ao retrocessoressecção monocular $(2 \mathrm{~B})(\mathrm{p}=0,266)$. Conclusão: Concluiu-se que, nos pacientes com exotropia intermitente do tipo básico, tanto para desvios entre $12^{\Delta}$ e $25^{\Delta}$ quanto para desvios entre $26^{\Delta}$ e $35^{\Delta}$, submetidos ao retrocesso dos retos laterais ou retrocesso-ressecção monocular, ambos os procedimentos podem ser considerados igualmente efetivos, não havendo diferença significante entre a magnitude da exotropia préoperatória e a correção obtida.
Descritores: Exotropia/cirurgia; Músculos oculomotores; Procedimentos cirúrgicos oftalmológicos; Estudo comparativo

\section{REFERENCES}

1. Prieto-Diaz J, Souza-Dias C. Estrabismo. 4a ed. São Paulo: Roca; 2002.

2. Ing MR, Nishimura J, Okino L. Outcome study of bilateral lateral rectus recession for intermittent exotropia in children. Ophthalmic Surg Lasers. 1999;30(2):110-7.

3. Souza-Dias C, Uesugui CF. Postoperative evolution of the planned initial overcorrection in intermittent exotropia: 61 cases. Binocul Vis Eye Muscle Surg. 1993;8(3):141-8.

4. Burian HM, Spivey BE. The surgical management of exodeviations. Trans Am Ophthalmol Soc. 1964;62:276-306.

5. Burke MJ. Intermittent exotropia. Int Ophthalmol Clin. 1985;25(4):53-68.

6. Jampolsky A. Management of exodeviations. In: Haoik GM, editor. Strabismus Symposium of the New Orleans Academy of Ophthalmology. St. Louis: MYear Book; 1962. p.140.

7. Valenzuela A. Tratamiento quirúrgico de la exotropia intermitente. Fatores predictivos de sus resultados. In: XII Congresso del Consejo Latinoamericano de Estrabismo. Buenos Aires, 1996. p.145-9.

8. Stoller SH, Simon JW, Lininger LL. Bilateral lateral rectus recession for exotropia: a survival analysis. J Pediatr Ophthalmol Strabismus. 1994;31(2):89-92.

9. Kushner BJ. Selective surgery for intermittent exotropia based on distance/ near differences. Arch Ophthalmol. 1998;116(3):324-8. Erratum in: Arch Ophthalmol 1998;116(6):834

10. Lee S, Lee YC. Relationship between motor alignment at postoperative day 1 and at year 1 after symmetric and asymmetric surgery in intermittent exotropia. Jpn J Ophthalmol. 2001;45(2):167-71.

11. Raab EL, Parks MM. Immediate postoperative overcorrection after recession of lateral recti: effect on the final result. In Manley DR editor, Symposium on Horizontal Ocular Deviations. St Louis: Mosby; 1971. p.174.

12. Richardson S, Gnanaraj L. Interventions for intermittent distance exotropia Cochrane Database Syst Rev. 2003;(2):CD003737. Review. Update in: Cochrane Database Syst Rev. 2006;3:CD003737.

13. Richard JM, Parks MM. Intermittent exotropia. Surgical results in different age groups. Ophthalmology. 1983;90(10):1172-7.

14. Ruttum MS. Initial versus subsequent postoperative motor alignment in intermittent exotropia. J AAPOS. 1997;1(2):88-91.

15. Keech RV, Stewart SA. The surgical overcorrection of intermittent exotropia J Pediatr Ophthalmol Strabismus. 1990;27(4):218-20.

16. Melek NM. La exotropia intermitente. Observaciones clínicas y quirúrgicas. Buenos Aires: Casa Ares; 1976.

17. Hardesty HH, Boynton JR, Keenan JP. Treatment of intermittent exotropia. Arch Ophthalmol. 1978;96(2):268-74.

18. Moore S. The prognostic value of lateral gaze measurements in intermittent exotropia. Am Orthopt J. 1969;19:69-71

\section{ABD ELETRÔNICO \\ A versão eletrônica dos Arquivos Brasileiros de Oftalmologia com textos completos está disponivel em:}

- ABD - Arquivos Brasileiros de Oftalmologia http://www.abonet.com.br

- SciELQ - Scientific Electronic Library Online http://www.scielo.org 